\title{
Incidence and risk factors for acute kidney injury associated to surgery for congenital heart disease
}

\author{
Incidencia y factores de riesgo de falla renal aguda asociados a la corrección quirúrgica \\ de cardiopatías congénitas
}

\author{
Consuelo Restrepo-de Rovetto ${ }^{1,2 *}$, Cesar Llanos², Gloria Silva ${ }^{1}$, Alexander Martínez ${ }^{1,2}$, \\ Margarita Torres ${ }^{1,2}$, Clímaco Muñoz ${ }^{1}$, Carlos Fragozo ${ }^{1}$, Jimena Daza ${ }^{1}$ y Erika Cantor ${ }^{1}$ \\ ${ }^{1}$ Clínica Imbanaco, Grupo Quirónsalud, Cali; ${ }^{2}$ Pediatric Department, Universidad del Valle. Cali, Colombia
}

\begin{abstract}
Background: Acute kidney injury (AKI) occurs frequently after cardiac surgery for congenital heart disease and it has a great impact on patient's prognosis. Objective: The aims of this study were to determine the incidence and risk factors for AKI in children undergoing cardiac surgery and its impact on mortality, duration of mechanical ventilation, ICU and total hospital length of stay. Methods: This was a historical cohort study of children 0 - 18 years of age who underwent cardiac surgery between 2012 and 2014. We used the Risk Adjustment for Congenital Heart Surgery-1 (RACHS) scale to evaluate risk of the surgery. AKI was defined in accordance to the Acute Kidney Injury Network (AKIN) criteria. Results: $A$ total of 485 patients were included. AKI occurred in 89 (18.3\%) patients during the study period. Risk factors for AKI were age < 2 years, cardiopulmonary bypass (CPB) time > $120 \mathrm{~min}$ and RACHS score > 3. AKI increased the mortality risk (OR: 5.82, 95\% Cl: 2.24-15.10) and the time in mechanical ventilation and ICU stay from 1 to 5 days and 6 to 12 days, respectively. Conclusions: Risk factors for AKI are younger age, higher RACHS score, and time of CPB greater than 120 minutes. AKI increases mortality, days on MV and ICU stay. In the present study AKIN scale allowed us to classify the severity of AKI and it correlated with prognosis after cardiac surgery.
\end{abstract}

Keywords: Acute kidney injury. Cardiac surgery. Risk factors. Congenital heart defects.

\section{Resumen}

Introducción: La insuficiencia renal aguda (IRA) ocurre frecuentemente después de las cirugías de cardiopatías congénitas e impacta el pronóstico del paciente. Objetivo: Determinar incidencia y factores de riesgo para IRA en niños sometidos a cirugía de cardiopatía congénita y su impacto en mortalidad, duración de ventilación mecánica, tiempo de hospitalización total y en Cuidados Intensivos (UCI). Métodos: Cohorte histórica de niños entre cero y 18 años sometidos a cirugía cardiaca entre 2012 y 2014. El riesgo de la cirugía fue calculado mediante la escala Risk Adjustment for Congenital Heart Surgery-1 (RACHS). La falla renal fue establecida de acuerdo a la escala de Acute Kidney Injury Network (AKIN). Resultados: Se incluyeron 485 pacientes. 89 pacientes (18.3\%) desarrollaron IRA durante el postquirúrgico. Los factores de riesgo para IRA fueron edad < 2 años, tiempo de bypass cardiopulmonar $>120$ minutos y escala de RACHS $>3$. La ocurrencia de IRA

\section{Correspondence:}

*Consuelo Restrepo-de Rovetto

E-mail: consuelorestrepomd@gmail.com
Available online: 22-02-2022 Rev Colomb Cardiol. 2021;28(5):70-76 www.rccardiologia.com 0120-5633 / @ 2020 Sociedad Colombiana de Cardiología y Cirugía Cardiovascular. Published by Permanyer. This is an open access article under the CC BY-NC-ND license (http://creativecommons.org/licenses/by-nc-nd/4.0/). 
aumento el tiempo de ventilación mecánica de 1 a 5 días, la estancia en UCl de 6 a 12 días y el riesgo de mortalidad (OR: 5.82, 95\% IC: 2.24-15.10). Conclusiones: Los factores de riesgo para IRA fueron menor edad, mayor escala de RACHS y de tiempo de bypass. La ocurrencia de IRA aumentó la mortalidad, días en ventilación mecánica y estancia en UCl. En el presente estudio la escala de AKIN permitió clasificar la severidad de AKI y se correlaciono con el pronóstico después de cirugía de cardiopatía congénita.

Palabras clave: Falla renal aguda. Cardiopatías congénitas. Cirugía cardiaca. Factores de riesgo.

\section{Introduction}

Acute kidney injury (AKI) is a frequent complication in children undergoing cardiac surgery for congenital cardiac disease ${ }^{1,2}$. Acute kidney injury network (AKI) can compromise clinical evolution and affect the prognosis of the patients. The number of days in mechanical ventilation, ICU stay and mortality increase up to $18 \% \%^{3-5}$ in patients with this complication. Even though this topic has been widely studied, most reports come from Europe, North America, and Australia, but there are a few studies in Latin America ${ }^{4,6}$ and no previous reports in Colombia.

The aims of this study were to determine the incidence, severity and risk factors of AKI in children undergoing cardiac surgery in a tertiary care center in Cali, Colombia and to evaluate its impact on mortality, duration of mechanical ventilation, ICU and total hospital length of stay.

\section{Methods}

After approval of the Institutional Review Board of Centro Médico Imbanaco de Cali S.A, we performed a historical cohort of pediatric patients undergoing cardiac surgery. We reviewed the cardiac registry to identify children from newborn to 18 years of age who underwent this procedure for congenital heart defects between January 2012 and June 2014. Cases with incomplete data, previous renal disease, and those who died during surgery were excluded (Fig. 1).

\section{Study variables}

We performed a search of the electronic medical records, anesthesia and surgical charts and collected the following variables:

\section{Pre-operative VARIABLES}

These included age, sex and pre-surgical creatinine. We used the RACHS scoring system to categorize the complexity of surgery ${ }^{7}$. This method is widely accepted for the evaluation of differences in outcomes of surgery for congenital heart disease. The score was determined for each patient by the cardiac surgery group and an anesthesiologist prior to surgery.

\section{INTRAOPERATIVE VARIABLES}

These variables included use and time of bypass, time of ischemia and hypothermia.

\section{Post-operative Variables}

Serum creatinine, total days on MV, mortality, total days in the ICU and hospital stay were also obtained from the electronic medical records.

\section{AKI definition}

The Acute Kidney Injury Network (AKIN) definition ${ }^{8}$ was used to define AKI. Serum creatinine prior to surgery was used to calculate baseline renal function. Increased in serum creatinine of $0.3 \mathrm{mg} / \mathrm{dl}$ were classified AKIN 1, doble baseline serum creatinine AKIN 2 and triple base line serum creatinine AKIN 3. We classified AKIN stage using the highest serum creatinine concentration identified during the entire length of ICU stay after cardiac surgery. We did not use urine output since it could be influenced by diuretic use.

\section{Statistical analysis}

We performed univariate analysis with chi-square test or Fisher's exact test for categorical variables. Continuous variables were compared using Student $t$ test or Mann-Whitney $U$ test. A logistic regression model was applied to determine risk factors associated with AKI. Model selection was performed using a backward selection methodology based on Akaike's Information Criteria. In the multivariable model we included variables that reported $p<0.20$ in the crude analysis. The odds ratio (OR) was estimated with its 


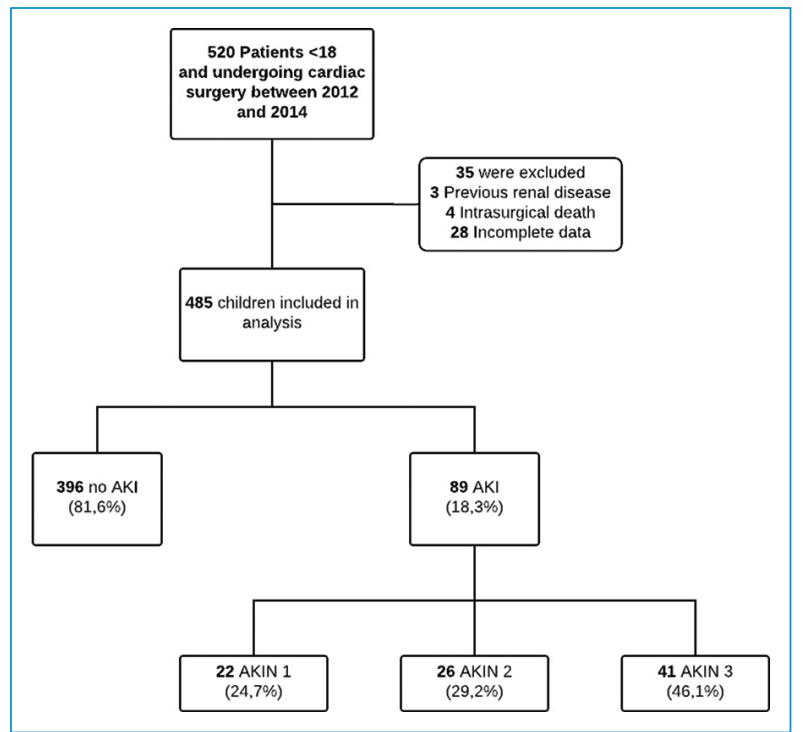

Figure 1. Patient selection and classification according to AKIN stage.

95\% confidence interval (Cl). Goodness-of-fit was evaluated with the likelihood ratio test and model deviance. We estimated crude OR and OR adjusted for age, time of CPB and RACHS scale to compare the clinical outcomes between groups. In the multivariable analysis, categories 4-6 of the RACHS scoring were combined due to the small number of children in these categories. All analyses were carried out using Stata 13 (STATA Corp, College Station, TX).

\section{Results}

\section{Study population and AKI incidence}

Table 1 shows the main characteristics of the patients who developed AKI compared to those without AKI. During the 30-month study period, 485 children who underwent cardiac surgery were included in the analysis: $84(17.3 \%)$ were neonates and $238(48.1 \%)$ were less than two years of age. Among the patients with AKI, $55.1 \%$ were male. According to the RACHS scale, $34.4 \%$ (167) of the procedures were at medium or high surgical risk (RACHS: 3-6). During the study period, the overall mortality rate was $14.4 \%$ (70/485), and the incidence of post-operative AKI was 18.3\% (89 cases; $95 \%$ Cl: $15.1 \%-22.0 \%)$. The most of these patients were classified as AKIN score $3(41 / 89)$. The incidence of AKI decreased gradually from year $1(23 \%)$ to year $3(11 \%)$.

\section{Risk factors for AKI development}

The univariate analysis showed that patients with AKI were younger (2.67 years \pm 0.23$)$ vs. the patients without AKI (3.65 years \pm 0.22 ). The use of ischemia was higher among AKI cases $(77.5 \%$ vs. $66.7 \% ; p=$ 0.046 ), and a higher proportion of cases had an ischemia time $>120 \mathrm{~min}(21.3 \%$ vs. $3.7 \%$ : $p<0.001)$. Proportion of patients undergoing CPB did no differ between the groups with and without AKI (91\% vs. $84.6 \% ; p=0.117$ ), but $50.6 \%$ of the cases with AKI were on CPB for more than 120 min vs. $10.8 \%$ without AKI $(p<0.001)$ (Table 1). Fig. 2 shows that there is a tendency to develop a more severe type of AKI among the patients with a longer CPB time. This difference was more notorious between the patients with $A K I$ stage 3 compared to patients without AKI and stages 1 and 2.

The multivariable logistic regression model identified age, RACHS score and CPB time as risk factors for AKI development. Neonates and children younger than two years of age had the highest cumulative risk of post-operative AKI (Table 2). The patients with RACHS category 3 had 3.74-fold the odds of developing AKI than those with RACHS category 1. Although, approximately half of the patients with RACHS category 4 to 6 developed AKI after cardiac intervention, evidence was insufficient to support differences between highrisk and low-risk procedures $(p=0.49)$ (Table 2).

CPB time was higher among the patients that developed AKI. $50 \%$ of patients with prolonged CPB time (>120 min) developed AKI postoperatively. The patients undergoing procedures with a CPB time between 121 and 180 min were 7 times more likely to develop AKI than those who underwent a CPB with a duration of $<60$ min $(p<0.001)$. The odds increased 10.9 -fold in patients with a CPB time of $>180 \mathrm{~min}(\mathrm{p}<0.001)$ (Table 2).

\section{AKI associated outcomes}

Children with AKI had increased time on MV. The median number of days on MV was greater for patients with AKI than for patients without it (5 vs. 1 day, $p<$ 0.001). In the adjusted model, we found that the odds of requiring MV for 2 days after surgery was 14.69-fold in children with AKI compared to patients without post-operative AKI (Cl 6.6-32.67, $\mathrm{p}<0.001$, Table 2).

The length of ICU stay was 12 days for patients with AKI and 6 days for patients without AKI (Table 1), and the odds of having an ICU stay $>7$ days was 3.99 -fold 
Table 1. Characteristics of the patients according to occurrence of AKI

\begin{tabular}{|c|c|c|c|}
\hline Variables & AKI $(n=89)$ & $\begin{array}{c}\text { No } \\
\text { AKI }(n=396)\end{array}$ & $\begin{array}{c}\mathbf{p} \\
\text { value }\end{array}$ \\
\hline $\begin{array}{l}\text { Age, } n(\%) \\
\leq 30 \text { days } \\
>30 \text { days } \leq 2 \text { years } \\
>2 \text { years }<13 \text { years } \\
\geq 13 \text { years }<18 \text { years }\end{array}$ & $\begin{array}{c}32(35.9 \%) \\
39(43.8 \%) \\
14(15.7 \%) \\
4(4.5 \%)\end{array}$ & $\begin{array}{c}52(13.1 \%) \\
199(50.2 \%) \\
122(30.8 \%) \\
23(5.8 \%)\end{array}$ & $<0.001$ \\
\hline $\begin{array}{l}\text { Sex, n }(\%) \\
\text { Female } \\
\text { Male }\end{array}$ & $\begin{array}{l}40(44.9 \%) \\
49(55.1 \%)\end{array}$ & $\begin{array}{l}188(47.6 \%) \\
208(52.5 \%)\end{array}$ & 0.590 \\
\hline $\begin{array}{l}\text { RACHS, n (\%) } \\
\text { Median (IOR) } \\
1 \\
2 \\
3 \\
4 \\
6\end{array}$ & $\begin{array}{c}3(2-3) \\
7(7.9 \%) \\
24(26.9 \%) \\
44(49.4 \%) \\
10(11.2 \%) \\
4(4.5 \%)\end{array}$ & $\begin{array}{c}2(1-3) \\
114(28.8) \\
173(43.7) \\
93(23.5 \%) \\
12(3.0 \%) \\
4(1.0)\end{array}$ & $<0.001$ \\
\hline CPB, n (\%) & $81(91.0 \%)$ & $335(84.6 \%)$ & 0.117 \\
\hline $\begin{array}{l}\text { CPB time, n (\%) } \\
0-60 \text { min } \\
61-120 \text { min } \\
121-180 \mathrm{~min} \\
>180 \mathrm{~min}\end{array}$ & $\begin{array}{l}23(25.8 \%) \\
21(23.6 \%) \\
33(37.1 \%) \\
12(13.5 \%)\end{array}$ & $\begin{array}{c}225(56.8 \%) \\
128(32.3 \%) \\
33(8.3 \%) \\
10(2.5 \%)\end{array}$ & $<0.001$ \\
\hline Ischemic, n (\%) & $69(77.5 \%)$ & $264(66.7 \%)$ & 0.046 \\
\hline $\begin{array}{l}\text { Ischemic time, } \mathrm{n}(\%) \\
0-60 \mathrm{~min} \\
61-120 \mathrm{~min} \\
121-180 \mathrm{~min} \\
>180 \mathrm{~min}\end{array}$ & $\begin{array}{c}42(47.2 \%) \\
28(31.5 \%) \\
16(17.9 \%) \\
3(3.4 \%)\end{array}$ & $\begin{array}{c}293(73.9 \%) \\
88(22.2 \%) \\
14(3.5 \%) \\
1(0.2 \%)\end{array}$ & $<0.001$ \\
\hline DHCA, n (\%) & $10(11.2 \%)$ & $14(3.5 \%)$ & 0.002 \\
\hline $\begin{array}{l}\text { MV duration, } \mathrm{n}(\%) \\
>2 \text { days } \\
\text { Median (IQR) }\end{array}$ & $\begin{array}{c}55(63.9 \%) \\
5(2-9)\end{array}$ & $\begin{array}{c}43(10.9 \%) \\
1(1-2)\end{array}$ & $<0.001$ \\
\hline $\begin{array}{l}\text { ICU length of stay } \\
>7 \text { days } \\
\text { Median (IOR) }\end{array}$ & $\begin{array}{c}60(68.2 \%) \\
12(4-21)\end{array}$ & $\begin{array}{c}142(35.9 \%) \\
6(4-9)\end{array}$ & $<0.001$ \\
\hline $\begin{array}{l}\text { Length of stay } \\
>7 \text { days } \\
\text { Median (IOR) }\end{array}$ & $\begin{array}{c}70(82.3 \%) \\
8(6-17)\end{array}$ & $\begin{array}{c}221(56.5 \%) \\
19(10-33)\end{array}$ & $<0.001$ \\
\hline Mortality, n (\%) & $40(44.9 \%)$ & $30(7.6 \%)$ & $<0.001$ \\
\hline
\end{tabular}

CPB: cardiopulmonary bypass; MV: mechanical ventilation; ICU: intensive care unit: DHCA: deep hypothermic circulatory arrest.

in children with AKI when compared to the ones without it (Cl 1.83-8.71, $\mathrm{p}<0.001$, Table 2).

In-hospital, mortality was higher in patients who developed post-operative AKI (AKI: 44.9\% (40/89) vs no AKI: $7.6 \%(30 / 396))$, and increased gradually with the AKIN scale risk (Fig. 3). After model adjustment, the odds of death were 5.82-fold higher among patients with AKI (CI 2.24-15.1, p < 0.001) (Table 2).

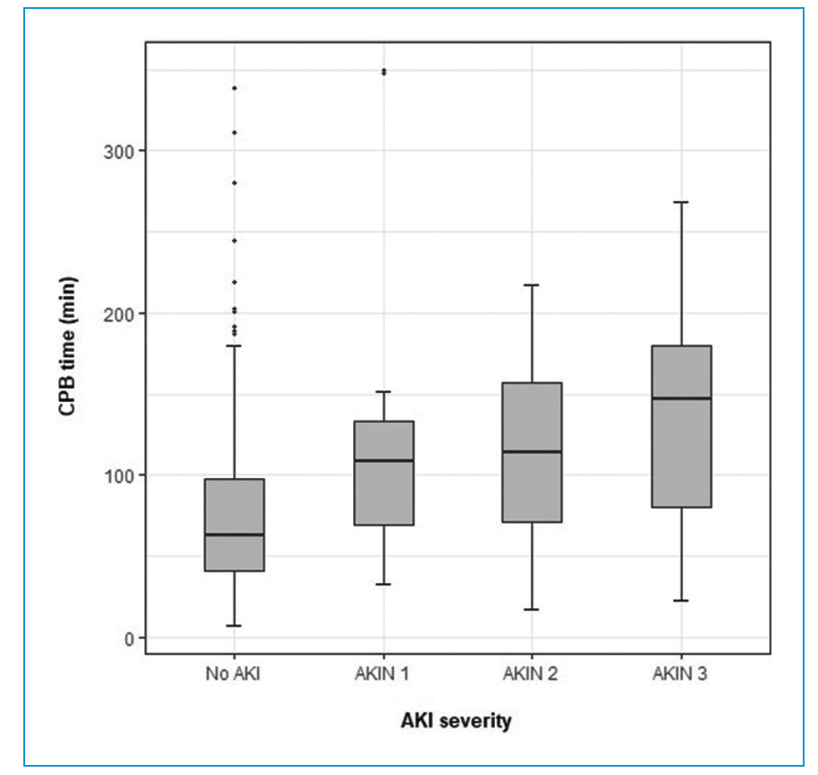

Figure 2. Severity of AKI according to CPB time.

\section{Discussion}

The results of this study showed that the incidence of AKI after cardiac surgery using the AKIN definition was $18.3 \%$, and morbidity and mortality increased with AKI severity. Neonates had higher risk of developing AKI when compared to older children.

The incidence of AKI using the AKIN scale was $18.3 \%$, compared with $11 \%$ reported prior to AKI definitions ${ }^{1}$. Later reports using the pRIFLE scale to define AKI reported $36 \%{ }^{9}$ and $20 \%{ }^{3}$. In a study comparing systems for identification of post-operative AKI in pediatric cardiac patients, the AKIN scale was more specific compared with the pRIFLE and KDIGO and detected mostly high-risk patients across all age groups ${ }^{10}$. Multiples studies have proven that the AKI scales allow for classification of AKI severity and also determines prognosis and mortality $3,4,11$. The AKIN scale in the present study was able to classify the severity of AKI and it correlated with prognosis. Of note, for AKI staging we only used increasing creatinine sincef urine output could be influenced by the use of diuretics ${ }^{12}$.

The incidence of AKI in our study was lower than estimates in previous studies ${ }^{5}$. This difference might be related to improvements in cardiac surgery techniques over the past decade. As reported in other studies, the AKI incidence decreased through the years of the program, from $23 \%$ in the first year to $11 \%$ in the third one, however the CPB duration has remained similar over the years ${ }^{13,14}$. Adjustment in anesthesia protocols, the 
Rev Colomb Cardiol. 2021;28(5)

Table 2. Risk factors and outcomes of acute kidney injury after cardiac surgery

\begin{tabular}{|c|c|c|c|}
\hline \multicolumn{4}{|c|}{ Risk Factors } \\
\hline \multirow[t]{2}{*}{ Variables } & \multicolumn{3}{|c|}{ Total $(n=485)$} \\
\hline & $\%(n)$ AKI & OR (CI 95\%) & p value \\
\hline $\begin{array}{l}\text { Age, } n(\%) \\
\leq 30 \text { days } \\
>30 \text { days } \leq 2 \text { years } \\
>2 \text { years }<13 \text { years } \\
\geq 13 \text { years }<18 \text { years }\end{array}$ & $\begin{array}{l}38.1 \%(32) \\
16.4 \%(39) \\
10.3 \%(14) \\
14.8 \%(4)\end{array}$ & $\begin{array}{c}1 \\
0.36(0.18-0.74) \\
0.15(0.06-0.36) \\
0.16(0.04-0.65)\end{array}$ & $\begin{array}{l}0.005 \\
0.000 \\
0.010\end{array}$ \\
\hline $\begin{array}{l}\text { RACHS } \\
1 \\
2 \\
3 \\
4,5,6\end{array}$ & $\begin{array}{c}5.8 \%(7) \\
12.2 \%(24) \\
32.3 \%(44) \\
46.7 \%(14)\end{array}$ & $\begin{array}{c}1 \\
1.71(0.67-4.34) \\
3.74(1.48-9.40) \\
1.55(0.43-5.54)\end{array}$ & $\begin{array}{l}0.260 \\
0.005 \\
0.497\end{array}$ \\
\hline $\begin{array}{l}\text { CPB time, min } \\
\quad<60 \\
61-120 \\
121-180 \\
>180\end{array}$ & $\begin{array}{c}9.3 \%(23) \\
14.1 \%(21) \\
50.0 \%(33) \\
54.5 \%(12)\end{array}$ & $\begin{array}{c}1 \\
1.55(0.79-3.05) \\
6.98(3.25-14.98) \\
10.87(3.63-32.53)\end{array}$ & $\begin{array}{l}0.203 \\
<0.001 \\
<0.001\end{array}$ \\
\hline \multicolumn{4}{|c|}{ Outcomes } \\
\hline & \multicolumn{3}{|c|}{ Total $(n=485)$} \\
\hline Variables & Crude OR [CI95\%] & $\begin{array}{l}\text { Adjusted OR } \\
\text { [CI 95\%]* }\end{array}$ & p value \\
\hline $\begin{array}{l}\text { MV duration } \\
>2 \text { days }\end{array}$ & 14.44 [8.40; 24.84] & 14.69 [6.60-32.67] & $<0.001$ \\
\hline $\begin{array}{l}\text { PICU length of stay } \\
>7 \text { days }\end{array}$ & $3.83[2.34 ; 6.28]$ & $3.99[1.83 ; 8.71]$ & $<0.001$ \\
\hline $\begin{array}{l}\text { Length of stay } \\
>7 \text { days } \\
\text { Mortality }\end{array}$ & $\begin{array}{c}3.59[.98 ; 6.49] \\
9.96[5.69 ; 17.42]\end{array}$ & $\begin{array}{c}2.81[1.10 ; 7.17] \\
5.82[2.24 ; 15.10]\end{array}$ & $\begin{array}{l}<0.001 \\
<0.001\end{array}$ \\
\hline
\end{tabular}

${ }^{*}$ Model adjusted for age, CPB time, RACHS scale.

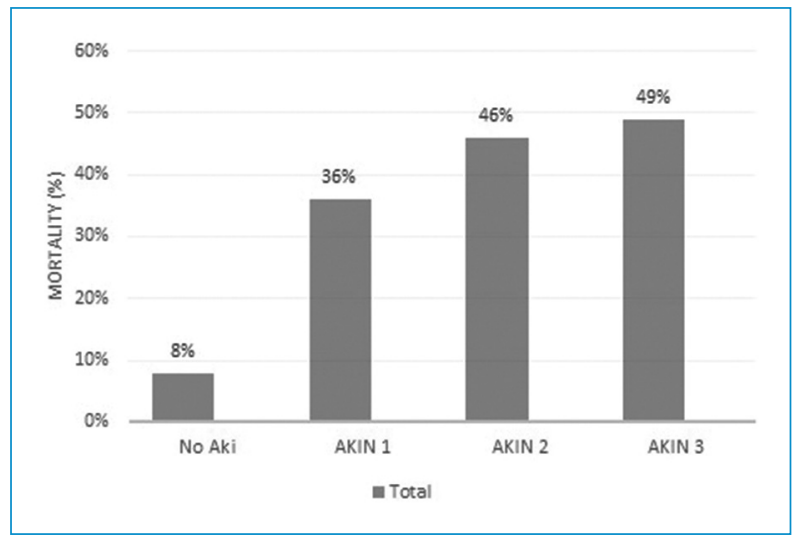

Figure 3. Mortality according to AKI severity.

use of pre-operative checklists, and recognition of highrisk patients are some of the changes that could explain this difference. Compared to other studies in Latin
America, AKI incidence in the present study was somewhat lower when compared to studies done in Brasil $(25 \%)^{4}$ and Mexico $(34 \%)^{6}$.

In our study, CPB time and younger age were the main factors in the development of AKI after cardiac surgery for congenital heart disease. The previous reports have shown that CPB is a risk factor for developing $A K I^{3-5,11,13}$. We found that CPB use, by itself, did not influence significantly the AKI risk ( $p$ 0.117), but time of CPB did, the longer the CBP time, the greater the risk of developing $\mathrm{AKI}$ and a higher AKIN stage.

Neonates were at higher risk of $\mathrm{AKI}$, in this age group the incidence of AKI has previously been reported to be as high as $60.9 \%$ using the pRIFLE criteria ${ }^{15}$ and $64 \%{ }^{16}$ and $62 \%{ }^{5}$ using the AKIN score definition. The higher incidence of $\mathrm{AKI}$ in neonates can be explained 
by body size, renal development related to gestational age, and birth weight.

The development of AKI increased mortality. There is a progressively higher mortality rate at each AKIN severity stage. Similar findings were reported by Alabbas et al..$^{5}$ in a study of 76 neonates performed in Canada who developed AKI after cardiac surgery. In that study, the mortality rate was $14 \%$ compared with $4 \%$ in neonates without AKI; increments in mortality rate were found in the AKIN 3 score.

The recent studies have shown that differences in mortality rate can extend beyond the immediate post-operative period in patients with AKI, especially in those with stage AKIN 3 or pRIFLE failure stage ${ }^{17}$. In a study of 418 patients with AKI after cardiac surgery, $22 \%$ died during the 2-year follow-up period ${ }^{18}$. The TRIBE-AKI study ${ }^{19}$ found that in 131 children who had AKI after cardiac surgery, $17 \%$ had hypertension, $8 \%$ had microalbuminuria, and $14 \%$ had a glomerular filtration rate less than $90 \mathrm{~mL} / \mathrm{min} / 1.73 \mathrm{~m}^{2}$ at 5 -year follow-up. These data emphasize the importance of long-term follow-up of renal function and blood pressure in patients with AKI after cardiac surgery.

Knowing the risk factors for post-surgical AKI may contribute to take preventive measures such as placement of peritoneal catheter during surgery in patients with prolonged CPB time and higher RACHS, in fact this has showed to improve early management of $\mathrm{AKI}^{20}$.

Among the limitations of this study, it was retrospective with the subsequent problems of insufficient data in the medical registries. It was a single center study with high proportion of neonates who are the ones with higher risk for AKI. Multicenter studies with a longer follow-up would be necessary to evaluate more the long term outcomes of these patients

AKI definitions have improved the diagnosis and treatment of AKI after cardiac surgery. New biomarkers, such as neutrophil gelatinase-associated lipocalin, kidney injury molecule 1 , and cystatin $C$, have been investigated and soon will guide the early detection and severity of AKI after cardiac surgery ${ }^{21,22}$. Serum cystatin $C$ concentration has been shown to predict $A K I$ as early as 8 hours after $\mathrm{CPB}^{23}$. Earlier recognition and intervention of AKI can improve management and prognosis. Future studies using these biomarkers will help to guide earlier clinical interventions in the management of AKI.

\section{Conclusions}

AKI is a frequent complication after cardiac surgery. Risk factors for AKI are younger age, higher RACHS score, and time of CPB greater than $120 \mathrm{~min}$. AKI increases mortality, days on MV, and ICU and total hospital stay. In the present study, the AKIN scale allowed us to classify the severity of AKI and it correlated with prognosis after cardiac surgery.

\section{Funding}

The authors declare they do not receive external funding.

\section{Conflicts of interest}

The authors do not have conflicts of interest.

\section{Ethical disclosures}

Protection of human and animal subjects. The authors declare that no experiments were performed on humans or animals for this study.

Confidentiality of data. The authors declare that they have followed the protocols of their work center on the publication of patient data.

Right to privacy and informed consent. The authors declare that no patient data appear in this article.

\section{References}

1. Skippen PW, Krahn GE. Acute renal failure in children undergoing cardiopulmonary bypass. Crit Care Resusc. 2005;7:286-91.

2. Rosner MH, Okusa MD. Acute kidney injury associated with cardiac surgery. Clin J Am Soc Nephrol. 2006;1:19-32.

3. Gil-Ruiz Gil-Esparza MA, Alcaraz Romero AJ, Romero Otero A, Gil Villanueva N, Sanavia Moran E, de la Blanca AR, et al. Prognostic relevance of early AKI according to pRIFLE criteria in children undergoing cardiac surgery. Pediatr Nephrol. 2014;29:1265-72.

4. Dos Santos MG, Carvalho PR. Acute kidney injury according to pediatric RIFLE criteria is associated with negative outcomes after heart surgery in children. Pediatr Nephrol. 2013;28:1307-14.

5. Alabbas A, Campbell A, Skippen P, Human D, Matsell D, Mammen C. Epidemiology of cardiac surgery-associated acute kidney injury in neonates: a retrospective study. Pediatr Nephrol. 2013;28:1127-34.

6. Reyes-Flandes EN, Herrera-Landero A, Bobadilla-González P, Núñez-Enríquez JC. Factores de riesgo asociados a insuficiencia renal aguda postoperatoria en pacientes pediátricos intervenidos de cirugía cardiaca que requirieron de circulación extracorpórea. Rev Chil Pediatr. 2017;88:209-15.

7. Jenkins KJ, Gauvreau K, Newburger JW, Spray TL, Moller JH, lezzoni LI. Consensus-based method for risk adjustment for surgery for congenital heart disease. J Thorac Cardiovasc Surg. 2002;123:110-8.

8. Mehta RL, Kellum JA, Shah SV, Molitoris BA, Ronco C, Warnock DG, et al. Acute kidney injury network: report of an initiative to improve outcomes in acute kidney injury. Crit Care. 2007;11:R31.

9. Zappitelli M, Bernier PL, Saczkowski RS, Tchervenkov Cl, Gottesman R, Dancea $A$, et al. A small post-operative rise in serum creatinine predicts acute kidney injury in children undergoing cardiac surgery. Kidney Int. 2009;76:885-92.

10. Lex DJ, Toth R, Cserep Z, Alexander SI, Breuer T, Sapi E, et al. A comparison of the systems for the identification of postoperative acute kidney injury in pediatric cardiac patients. Ann Thorac Surg. 2014;97:202-10.

11. Li S, Krawczeski CD, Zappitelli M, Devarajan $\mathrm{P}$, Thiessen-Philbrook H, Coca SG, et al. Incidence, risk factors, and outcomes of acute kidney injury after pediatric cardiac surgery: a prospective multicenter study. Crit Care Med. 2011;39:1493-9. 
Rev Colomb Cardiol. 2021;28(5)

12. Yuan SM. Acute kidney injury after pediatric cardiac surgery. Pediatr Neonatol. 2019;60:3-11.

13. Pedersen K, Povlsen J, Christensen S, Pedersen J, Hjortholm K, Larsen $\mathrm{S}$, et al. Risk factors for acute renal failure requiring dialysis after surgery for congenital heart disease in children. Acta Anaesthesiol Scand 2007;51:1344-9.

14. Kramer RS, Herron CR, Groom RC, Brown JR. Acute kidney injury subsequent to cardiac surgery. J Extra Corporeal Technol. 2015;47: 16-28.

15. Aydin SI, Seiden HS, Blaufox AD, Parnell VA, Choudhury T, Punnoose A, et al. Acute kidney injury after surgery for congenital heart disease. Ann Thorac Surg. 2012;94:1589-95

16. Morgan CJ, Zappitelli M, Robertson CM, Alton GY, Sauve RS, Joffe AR, et al. Risk factors for and outcomes of acute kidney injury in neonates undergoing complex cardiac surgery. J Pediatr. 2013;162:120-7.e1.

17. Watkins S Williamson K Davidson M Donahue B. Long-term mortality associated with acute kidney injury in children following congenital cardiac surgery. Pediatr Anesth. 2014;24:919-26.
18. Hirano D, Ito A, Yamada A, Kakegawa D, Miwa S, Umeda C, et al. Independent risk factors and 2-year outcomes of acute kidney injury after surgery for congenital heart disease. Am J Nephrol. 2017;46:204-9.

19. Greenberg JH, Zappitelli M, Devarajan P, Thiessen-Philbrook HR, Krawczeski C, Li S, et al. Kidney outcomes 5 years after pediatric cardiac surgery: the TRIBE-AKI study. JAMA Pediatr. 2016;170:1071-8.

20. Alkan T, Akcevin A, Turkoglu H, Paker T, Sasmazel A, Bayer V, et al. Postoperative prophylactic peritoneal dialysis in neonates and infants after complex congenital cardiac surgery. ASAIO J. 2006;52:693-7.

21. Toda $Y$, Sugimoto K. AKI after pediatric cardiac surgery for congenital heart diseases-recent developments in diagnostic criteria and early diagnosis by biomarkers. J Intensive Care. 2017;5:49.

22. Jefferies JL, Devarajan P. Early detection of acute kidney injury after pediatric cardiac surgery. Prog Pediatr Cardiol. 2016:4:19-6.

23. Hassinger AB, Backer CL, Lane JC, Haymond S, Wang D, Wald EL. Predictive power of serum cystatin $C$ to detect acute kidney injury and pediatric-modified RIFLE class in children undergoing cardiac surgery. Pediatr Crit Care Med. 2012;13:435-40. 